J. Perinat. Med.

3 (1975) 180

\section{The influence of intra-uterine surgery and of fetal intravenous nutritional supplements 'in utero' on plasma free amino acid homeostasis in the pregnant ewe}

\author{
Maureen Young, Gyula Soltesz*, David Noakes, Jenny Joyce, \\ I. R. McFadyen**, B. V. Lewis*** \\ Department of Gynecology, St. Thomas's Hospital Medical School, \\ London S. E. 1 and Department of Obstetrics \\ Royal Veterinary College Field Station, Hawkeshead House North Mimms, \\ Herts.
}

Received January 27, 1975. Accepted March 27, 1975.
It is well known that intra-uterine surgery for the introduction of indwelling catheters in utero' into the blood vessels of the fetal lamb causes some disturbance of homeostasis for a period of 5-7 days following the operation (SHELLEY [22]). This includes nitrogen metabolism, for Mellor and Slater [18] have described a fall in concentration of total $\alpha$-amino $N$ and urea in the allantoic fluid following surgery, together with a fall in the maternal plasma urea concentration. Observations of the changes in the fetal and maternal plasma free amino acid concentration following hysterotomy formed an important control in an investigation into the influence of an intravenous feeding supplement 'in utero' on fetal growth rate in which an infusion of amino acids and glucose was given into the fetal jugular vein for a period of 14 days (McFADYEN et al. [17]). The findings from the analysis of the plasma samples collected from the ewes and their fetuses during this investigation, are presented in this paper. An attempt has been made to relate them to the blood levels of urea and glucose observed. Total parenteral alimentation has been used previously in the adult sheep to study the amino acid metabolism in this species (TAO et al. [27]).

\section{Curriculum vitae}

GYula Soltész was born in 1942. 1960-66 studies in medicine at the University Medical Scbool, Pécs, Hungary. Clinical and research work in neonatal medicine since 1965 at the Department of Pediatrics, University of Pécs. In 1972-73 WeLLCOME research fellow at the Dept. of Obstetrics and Gynecology, St. Thomas's Hospital, London. Current studies deal with neonatal aminoacid and glucose metabolism.

\section{Material and methods}

\subsection{Experimental material}

The general care of the Clun ewes and the anesthetic and surgical procedures used for the cannulation of the fetal jugular vein, have all been described (McFADYEN et al. [17]). Ewes,

* Wellcome Trust Fellow. Present address: Department Pediatrics University of Pécs, Pécs/Hungary.

** Consultant in Obstetrics at Clinical Research Centre, Northwick Park Hospital, Watford Road, Harrow, Middx./ England.

*** Consultant in Obstetrics, Watford General Hospital, Watford, Herts./England. 
115-128 days pregnant, were studied, 11 in the 1972 and 12 in the 1973 lambing season. The methods of assessing changes in fetal weight and of giving the nutritional supplement differed in the two years.

In 1972, the fetuses were taken out of the uterus at surgery and weighed with the umbilical cord intact. Intravenous feeding 'in utero' was started 24 hours after surgery, $125 \mathrm{ml}$. Trophysan Sorbitol being given during one hour on each week day. Fetal and maternal jugular vein blood samples were taken before the infusion started and fetal blood was collected after the infusion had finished. The ewe and fetus were sacrificed after 13 days and the fetal weight was compared with that observed at hysterotomy.

In 1973, the fetuses were not weighed at surgery and the experimental trauma was thus less than in 1972. Intravenous feeding was, again, started after 24 hours and given as a continuous infusion for 14 days, $200 \mathrm{ml}$. 'Aminosol Glucose' each day. The fetal lamb's weight was compared with that of its uncatheterised twin at sacrifice; $5-7 \mathrm{ml}$ fetal and maternal jugular vein blood samples were taken on Mondays, Wednesdays and Fridays about 11 a. m. in both the 1972 and 1973 seasons.

\subsection{Nutritional supplement}

The nutritional supplement infused was equivalent to $20 \%-25 \%$ of the normal-fetal nitrogen retention per day, together with the carbohydrate energy source; the basis for the nitrogen and carbohydrate requirements (Tab. I) are described in the appendix.

The commercial solutions available for intravenous infusion contained similar proportions of nitrogen and carbohydrate to these requirements and the composition of the two fluids Trophysan in 1972 and 'Aminosol Glucose' in 1973, are

Tab. I. Estimated daily requirements of amino N, glucose, calories and oxygen for a $3 \mathrm{~kg}$ fetal lamb expressed in $\mathrm{g}$ and in $\mathrm{mg} \mathrm{kg} \mathrm{kg}^{-1}, \mathrm{~min}^{-1}$.

\begin{tabular}{lll}
\hline & \multicolumn{1}{c}{$\mathrm{g} /$ day } & $\mathrm{mg} / \mathrm{kg} \mathrm{min}$ \\
\hline Amino N & 1.6 & 0.74 \\
Glucose & 34 & 8.0 \\
Calories & $133 \mathrm{Kcal}$ & $30 \mathrm{cal}$ \\
Oxygen & $12 \mathrm{~L}$ & $\mathrm{ml}$ \\
\hline
\end{tabular}

'Tab. II. Quantity of amino acids and carbohydrate infuscd into a fetal lamb, $m$ moles day ${ }^{-1}$, for 'Trophysan' (1972) and 'Aminosol glucose' (1973).

\begin{tabular}{|c|c|c|}
\hline & $\begin{array}{c}1972 \\
\text { Trophysan } \\
125 \mathrm{ml} \\
\mathrm{m} \mathrm{m}\end{array}$ & $\begin{array}{l}1973 \\
\text { Aminosol glucose } \\
200 \mathrm{ml} \\
\text { s daily }\end{array}$ \\
\hline Aspartate & - & 3.28 \\
\hline Threonine & 2.85 & 1.71 \\
\hline Sstine & - & 1.97 \\
\hline Glutamate & - & 9.36 \\
\hline Proline & - & 5.00 \\
\hline Glycine & 83.30 & 1.57 \\
\hline Alanine & - & 2.13 \\
\hline Valine & 3.93 & 3.57 \\
\hline Cystinc & - & 0.29 \\
\hline Methionine & 3.36 & 1.11 \\
\hline Isolcucinc & 2.60 & 2.50 \\
\hline Leucine & 4.12 & 4.74 \\
\hline Tyrosine & - & 0.41 \\
\hline Phenylalınine & 2.79 & 1.90 \\
\hline Lysine & 5.75 & 3.20 \\
\hline Histidine & - & 0.98 \\
\hline Tryptophan & 0.98 & 0.35 \\
\hline Arginine & 0.59 & 1.19 \\
\hline Total amino $\mathrm{N}$ & 110.27 'DL' & $45.2^{\circ} \mathrm{L}$ ' \\
\hline or & $1.54 \mathrm{~g}$ & $0.63 \mathrm{~g}$ \\
\hline Glucose & - & $10.00 \mathrm{~g}$ \\
\hline Sorbitol & $12.3 \mathrm{~g}$ & - \\
\hline Dialysable & & \\
\hline polypeptide & - & $33.0 \mathrm{~g}$ \\
\hline
\end{tabular}

shown in Tab. II; they are expressed as the total quantity of each amino acid, together with the total amino $\mathrm{N}$ and carbohydrate, given per 24 hours. The 'Trophysan' contained a mixture of eight essential amino acids, six were in the racemic form, glycine to provide the nonessential nitrogen, and sorbitol as the energy source. 'Aminosol Glucose' was a casein hydrolysate containing 18 amino acids and 30\% polypeptides, with glucose as the calorie source.

\subsection{Techniques}

The individual amino acids were measured by ion-exchange chromatography using the single column gradient-elution technique (TECHNICON Instruments Co., Basingstoke, England). $0.5 \mu$ mole norleucine, internal standard, was added to $0.6-1.5 \mathrm{ml}$ plasma, and the proteins precipitated with 4 vols saturated picric acid. The supernatant was stored at $-10^{\circ} \mathrm{C}$ and the excess picric acid 
removed before analysis on a Dowex column (STEIN and MOore [24]). Twenty amino acids were estimated: Glutamine and asparagine were partially hydrolysed by the method and the remainder of each was eluted with threonine and included in this value. Proline was not measured. The error was $5 \%$. Blood glucose was estimated by the glucose oxidase method BoEHRINGER (Mannheim) and blood urea by the urease method and NESSLER color reaction (ARCHER and Robb [2]).

\section{Results}

Because of the continuous infusion, blood sampling was more successful during the second season 1973, and these results are described while those from 1972 are shown where they are relevant to the conclusions from 1973. Control maternal samples were taken before anesthesia, and the control fetal plasmas immediately after cannulation of the fetal jugular vein; all the post-operative samples were compared with these using the two tailed Student ' $t$ ' test.

A definite pattern of change was observed in the mean plasma free amino acid levels in both control catheterised fetuses and infused fetuses, and their respective mothers; but, due to the wide scatter of the results, relatively few of them were significantly different from the control preoperative levels, and will be indicated in the text and Tabs. III A, B, C and D.

\subsection{Fetal plasma amino acid changes}

2.1.1 Control catheterised fetuses (Tab. IIIA) During the 20-30 minutes required to replace the fetal head in the uterus and to close both the uterine incision and the maternal abdominal wall, the fetal plasma total $\alpha$-amino $\mathrm{N}$ rose by about $13 \%$ from $3.72 \mathrm{mM}$ to $4.19 \mathrm{mM}$. There were varying changes in the individual amino acid concentrations; a $40 \%$ rise occurred for taurine, $12 \%$ for serine, $21 \%$ for threonine and $44 \%$ for $\alpha$-amino butyrate, with smaller increases in alanine and 1 and 3 methyl histidine. The levels of the branched chain amino acids were little changed. Falls of $13 \%, 10 \%$ and $30 \%$ were observed in the basic amino acids ornithine, lysine, histidine and arginine respectively, together with a $7 \%$ reduction in glycine.
Twenty-four hours following the operation, the most prominent feature of the amino acid pattern was a fall of $30 \%$ in glutamate levels, $18 \%$ in glycine and $32 \%$ in alanine values $(\mathrm{P}<0.001)$; reductions were also observed for the branched chain amino acids valine $17 \%$, isoleucine 32\% $(\mathrm{P}<0.05)$ and leucine $9 \%$, and for tyrosine $(P<0.005)$. $\alpha$-amino butyrate and 1 and 3 methyl histidine continued to rise and a further small reduction occurred in ornithine levels.

On the second post-operative day, the plasma amino acid levels were indicative of the pattern during the subsequent 14 days. Glycine levels returned to control values, but glutamate ( $P$ $<0.05)$ and alanine $(P<0.001)$ remained low.

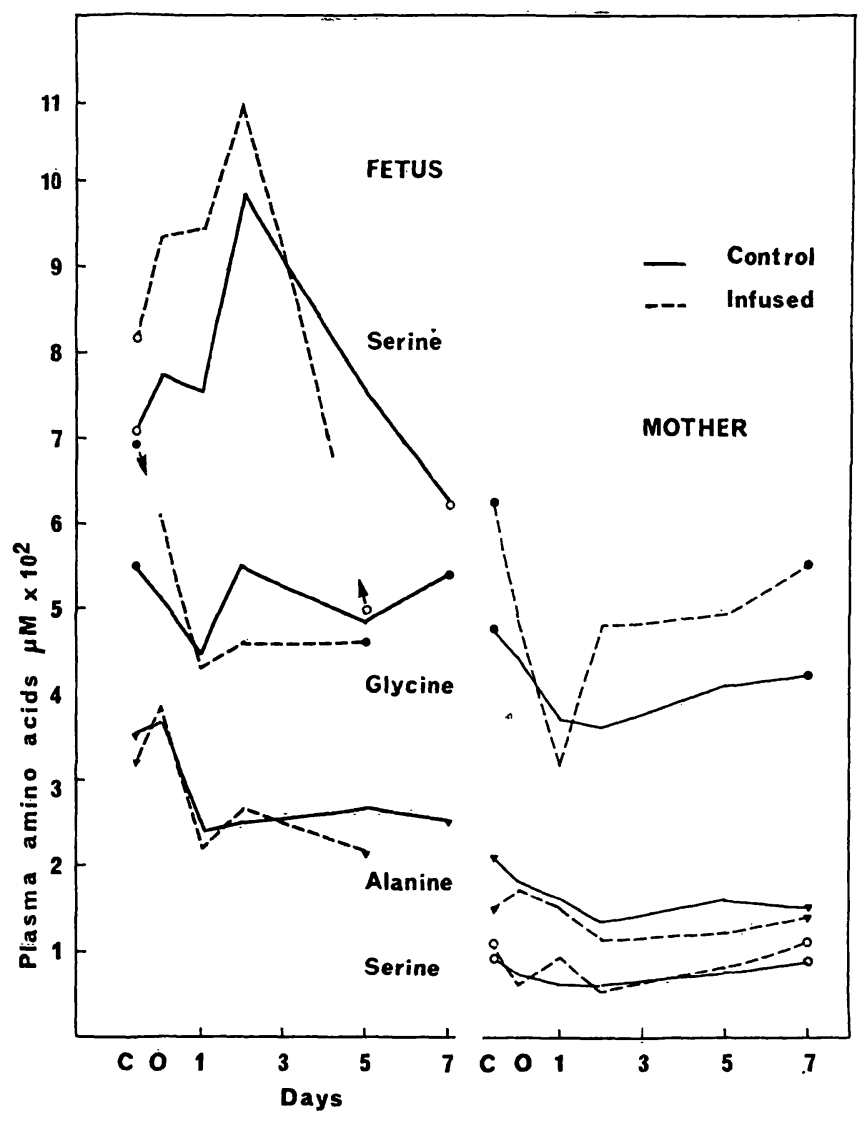

Fig. 1. To show the post-operative fall in fetal plasma glycine and alanine, and the temporary rise in serine. Infusion of amino acids and glucose into the fetal circulation did not influence the changes.

A comparable fall in maternal glycine also occurred, but the changes in alanine and serine were small.

The mean values have been taken from Tab. III. On the time scale, $\mathrm{C}=$ pre-operative, and $\mathrm{O}=$ postoperative levels. 


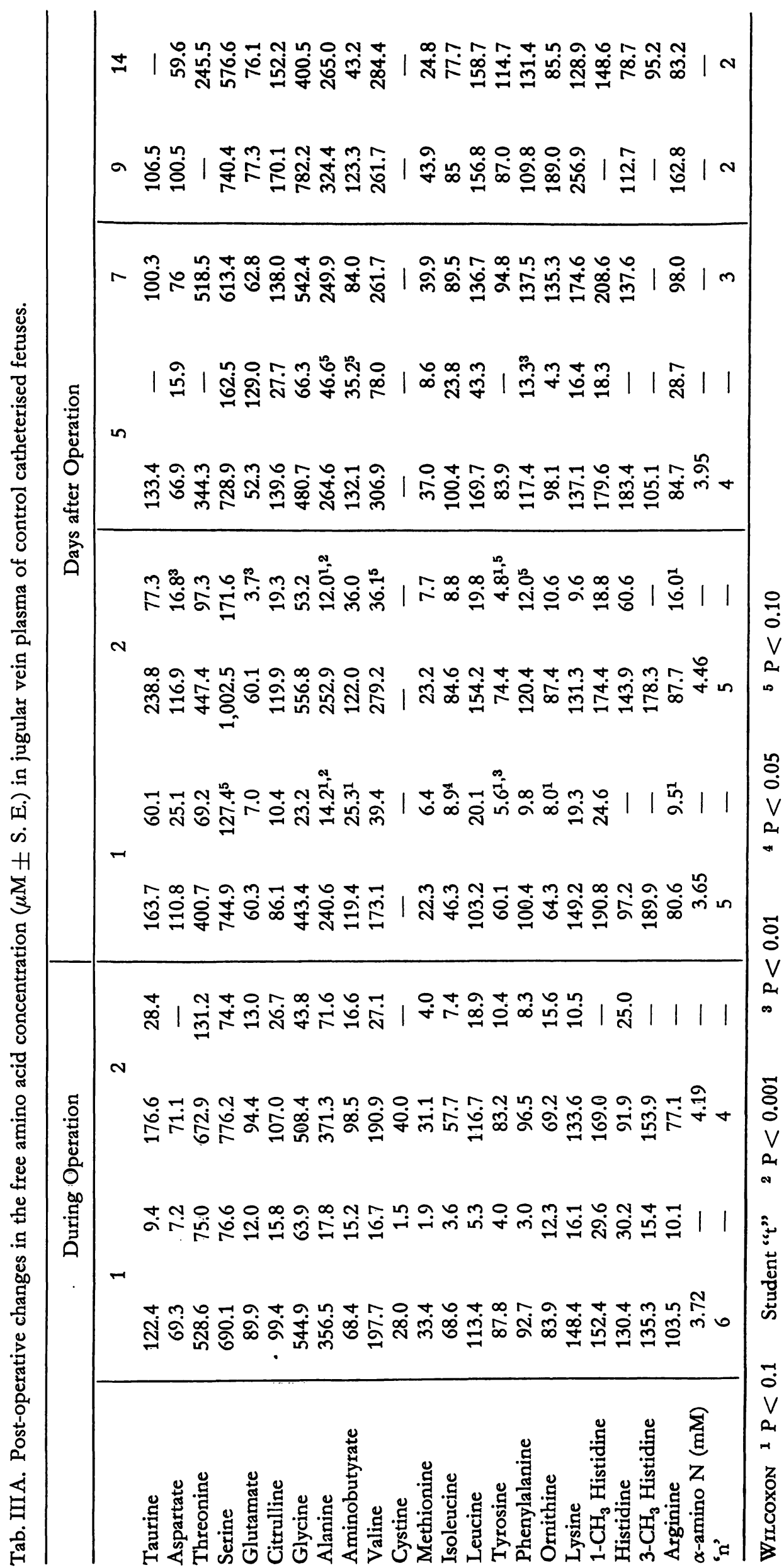




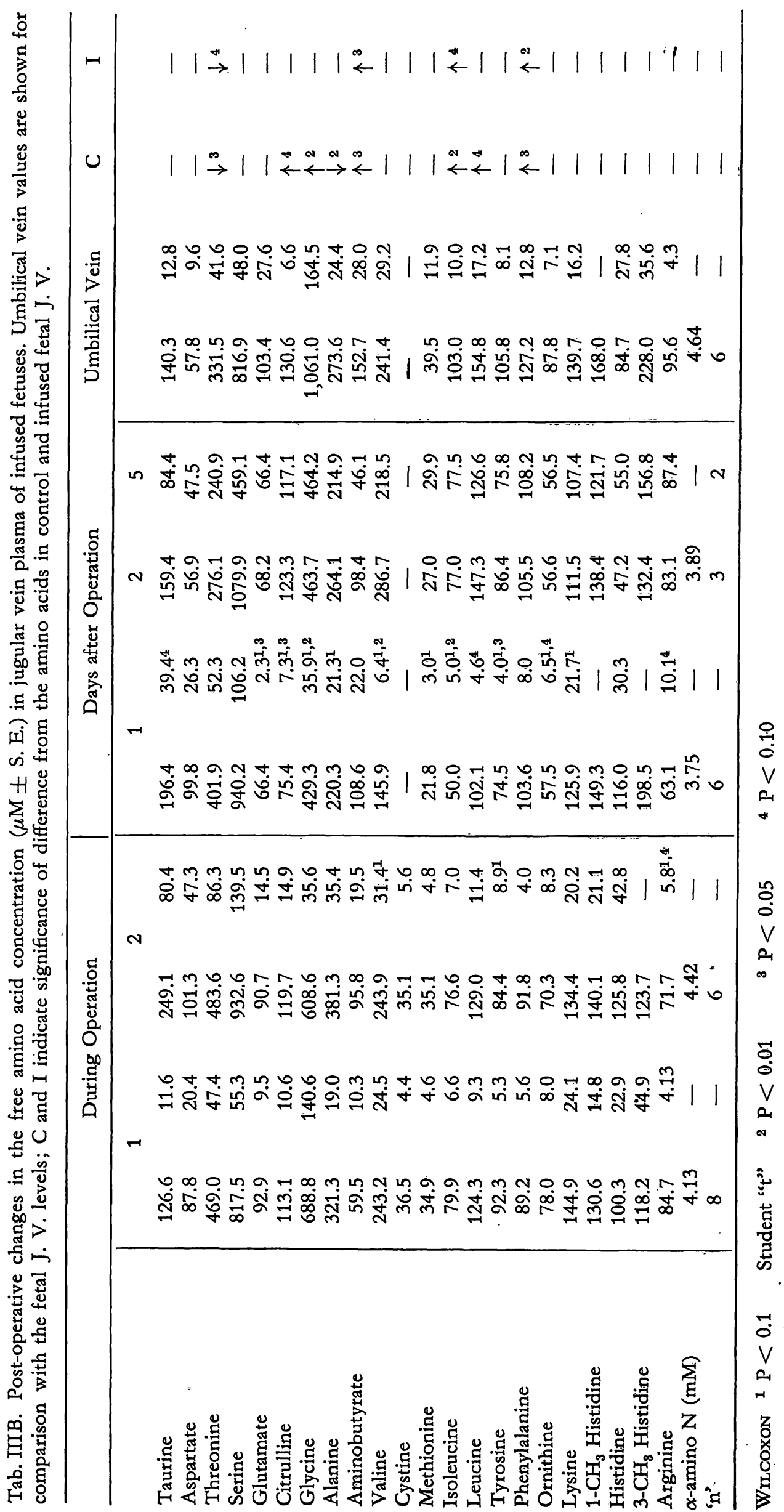


Serine concentration showed a peak at $45 \%$ above the control value on the second postoperative day and, subsequently, declined to the control value (Fig. 1). The branched chain amino acids became elevated by $42 \%$ for valine, $23 \%$ for isoleucine and $36 \%$ for leucine, and remained high; the basic amino acid concentrations remained near to their control levels. Taurine and $\alpha$-amino butyrate were continuously elevated at double their control levels and the methyl histidines also remained high. Citrulline concentration also rose by $20 \%$.

\subsubsection{Infused fetuses (Tab. IIIB)}

The changes during hysterotomy and those 24 hours after operation were similar to those just described for these periods in the control group, with a catheter only in the fetal jugular vein. The rise in total $\alpha$-amino $N$, and taurine $49 \%$ was more marked during surgery. The falls were significant the day after surgery for glutamate $(P<0.05)$ citrulline $(P<0.05)$ and alanine $(P<0.005)$; for the neutral branched chain, valine $(P<0.005)$, isoleucine $(P<0.005)$ and leucine $(P<0.1)$, and for the basic amino acids ornithine $(P<0.10)$ and arginine $(P$ $<0.10)$.

During the subsequent infusion period, the data is sufficient to suggest that the 'Aminosol Glucose' had no marked influence on plasma free amino acid homeostasis. This is shown in Fig. 2 in which the levels of three straight chain neutral amino acids, serine, glycine and alanine, three branched chain neutral, valine, isoleucine and leucine, and three basic, lysine, histidine and arginine, amino acid levels are shown throughout the infusion period in an individual fetus from each of the two groups, control and infused. A relative lability of the neutral straight chain free amino acid levels is observed in both the fetuses, and their mothers, in the two groups in comparison with the constancy of the neutral branched chain and basic amino acid levels. The outcome of both pregnancies was good. The infused fetus (No. 8) weighed $2.86 \mathrm{~kg}$ at 129 days in comparison with its twin of $3.01 \mathrm{~kg}$, (MCFADYEN et al. [17]). The control fetus (No. 5) weighed $3.83 \mathrm{~kg}$ at birth, by spontaneous premature delivery at 130 days, but there was no twin with which to compare this weight. The mother of the control fetus lost $3.5 \mathrm{~kg}$ weight during 14 days, while that of the infused fetus gained $5.5 \mathrm{~kg}$.

\subsubsection{Uncatheterised fetuses}

Umbilical vein blood was collected from six uncatheterised twins of experimental control or infused fetuses, which had remained undisturbed 'in utero' for 5-22 days following surgery to the sibling. The samples were taken quickly, following light Nembutal anesthesia and hysterotomy, by puncturing the vessel with a large needle and syringe, and the results are shown in Tab. IIIA. A comparison of the levels with those of the control fetal jugular vein in Tab. III A show that they have significantly higher straight chain, glycine $(P<0.02)$, alanine $(P<0.02)$ and branched chain amino acid concentrations, isoleucine $(P<0.02)$ and leucine $(P<0.10)$ ranging from $20-100 \%$ of the jugular vein values. These differences were not so marked when a comparison was made with the control jugular vein levels of the infused fetuses.

\subsubsection{Fetuses in the 1972 season}

Only one fetal blood sample was collected during the operation. A comparison of the composition of this plasma with that collected 24 hours after the hysterotomy showed a fall in total $\alpha$-amino $\mathrm{N}$ from 5.94 and $3.84 \mathrm{mM}$ in the control and infused fetuses, to $3.49 \mathrm{mM}$ and $3.69 \mathrm{mM}$ respectively. The falls in glutamate, glycine and alanine were marked, usually exceeding $50 \%$ of the control value; the fall in the branched chain and basic amino acids was also more marked than in the 1973 fetuses and recovery to the control levels did not occur during 13 days.

In the infused lambs, the levels of the essential amino acids contained in the Trophysan, rose gradually during the 13 days of observation. This is shown in Fig. 3, in which the plasma changes in three straight chain neutral, three branched chain neutral and three basic amino acids are shown for a control and an infused fetus together with their respective mothers. The glycine and valine levels in the infused lamb rose fourfold, while that of leucine doubled. No rise in isoleucine nor lysine and arginine was observed. 

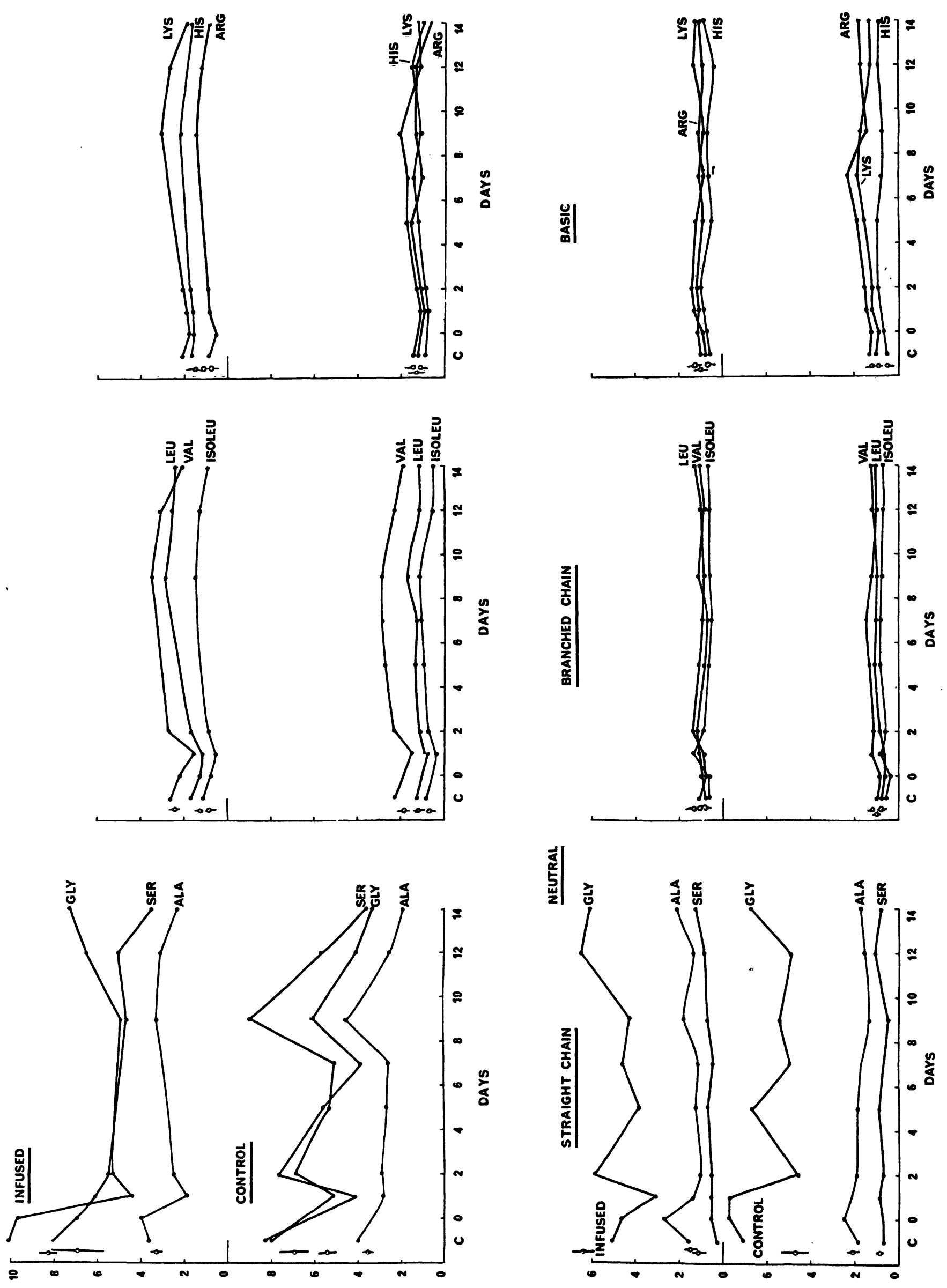

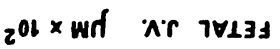

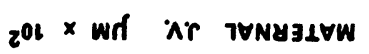

Fig. 2. Some free plasma amino acid values measured at intervals over 14 days in one infused and one control fetus and the corresponding mothers (1973). The straight chain neurral values were labile, but the branched chain neutral and basic amino acids levels more constant.

$\mathrm{C}=$ pre-operative $\mathrm{O}=$ post-operative 


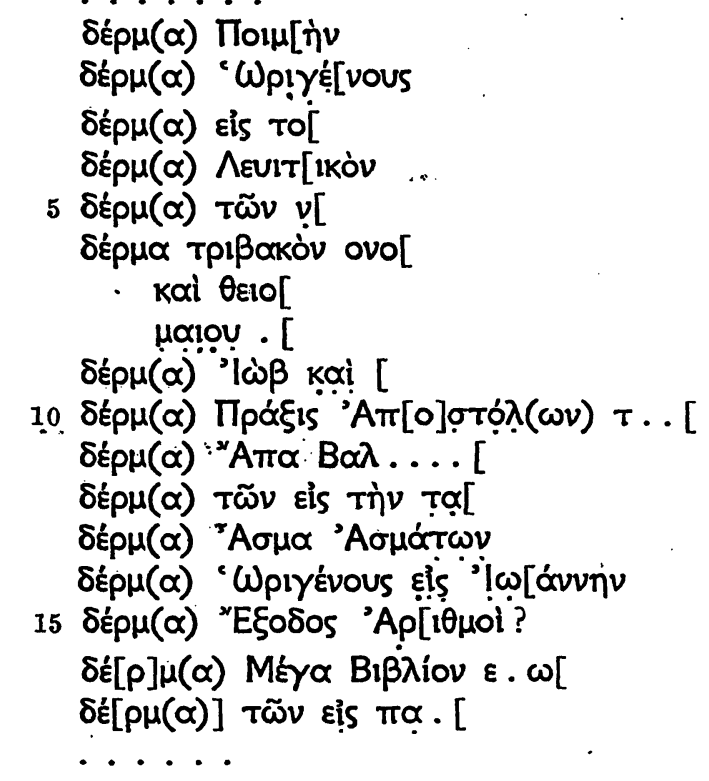

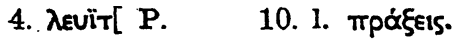

3. It is likely that this refers to another work of Origen's and that the scribe did not bother to repeat the name.

5. This and the similar entries in 11.12 and 17 are puzzling. Does the genitive imply that the books in question were selections or anthologies or that they were volumes of an incomplete set? Instead of $\nu, \pi$ might be read, but $\pi$ [poф $\eta \tau \tilde{\omega} \nu$ is improbable.

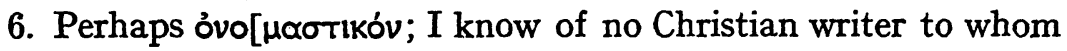
this entry could. refer.

10. The end of this line is blurred; a stroke reaching below the line after the $\lambda I$ have interpreted as a mark of abbreviation; but it

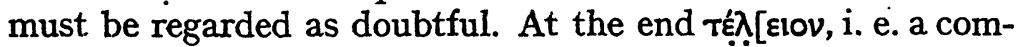
plete copy (cf. tpıßoxòv above), would be a possible reading.

11. This is the most puzzling of the entries. The first six letters of the title are quite clear, except that $v$ could be read for $\pi$ (one form of $v$ which the scribe employs is almost indistinguishable from $\pi$ ). The reading given in the text does not seem very likely because (i) I can find no trace of a Christian writer whose name begins with Bal ... (ii) it would be surprising to find the prefix ơrro in a text of this date and of this kind. But I can suggest no other solution. 


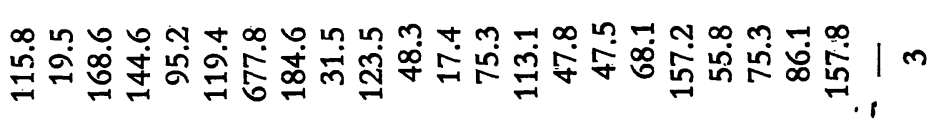
ㄱ

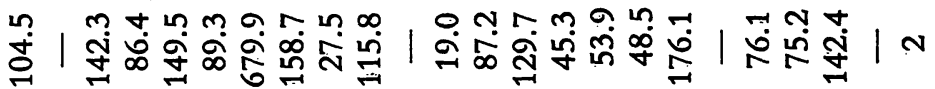

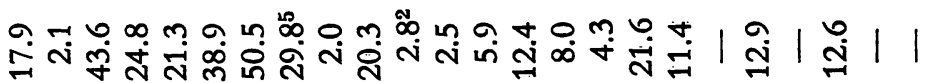

a

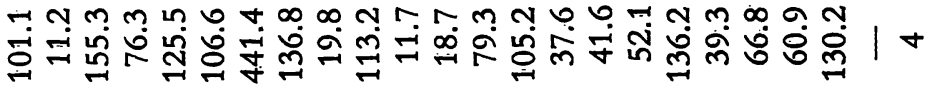

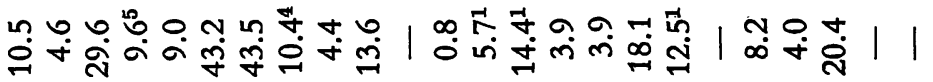

$r$

ง m ง.

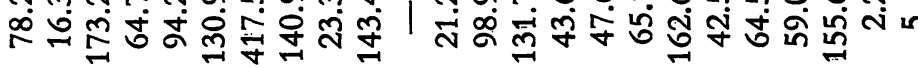

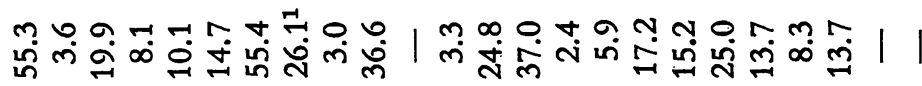

in

и $m$ ก п -

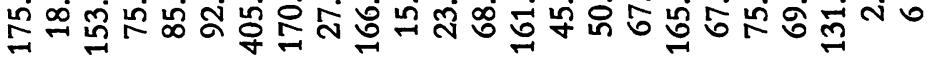

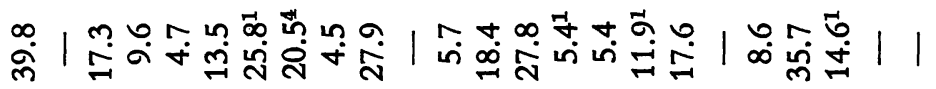
$N$

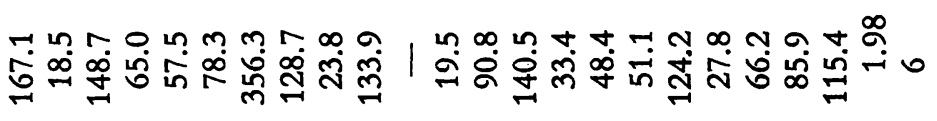

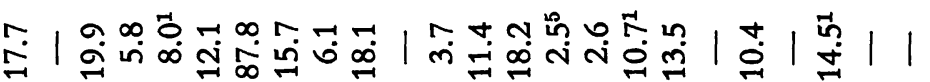

$\rightarrow$

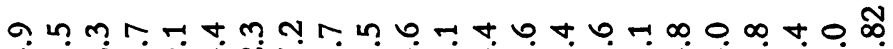

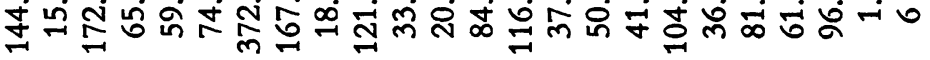

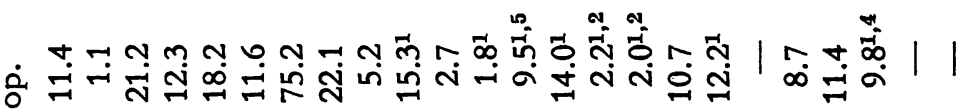

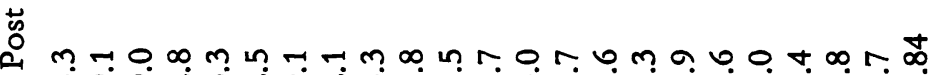

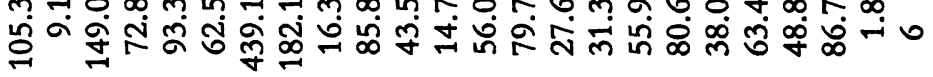

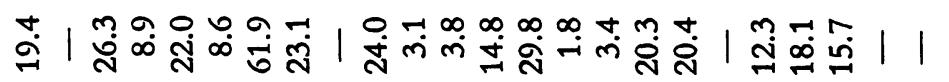

ת t m

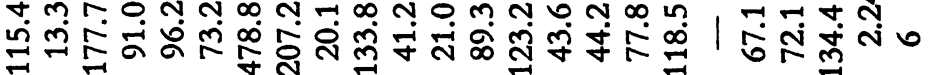


พ

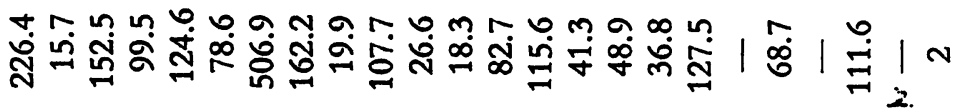

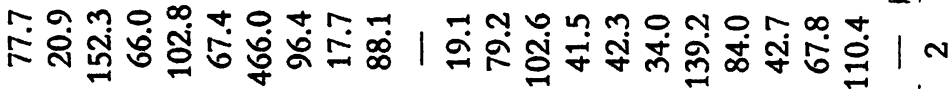

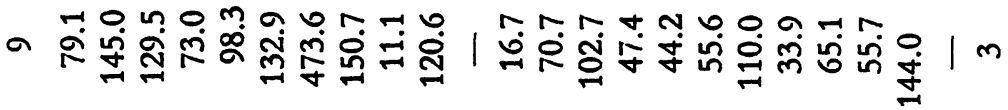

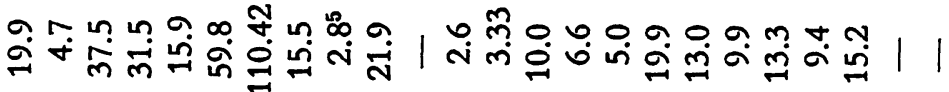
r

舟

ลั

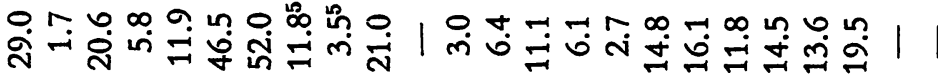
in

オ

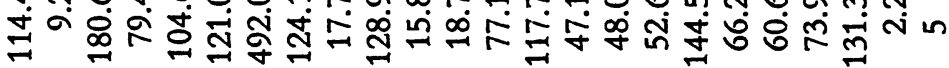

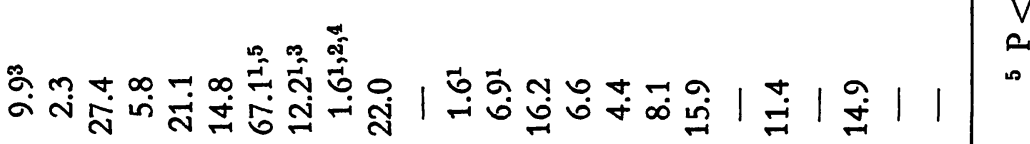

N

ก웅

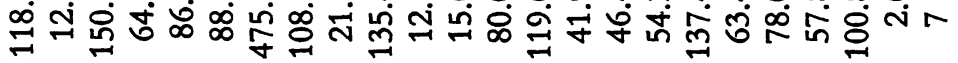

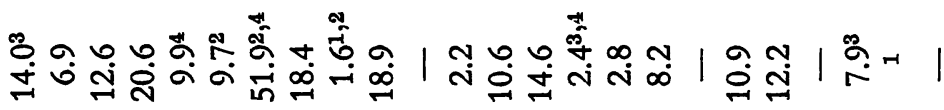

$\rightarrow$

ำ mm m

ถิ่

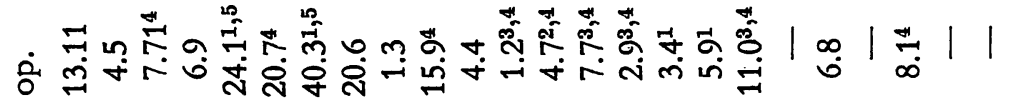
范 n

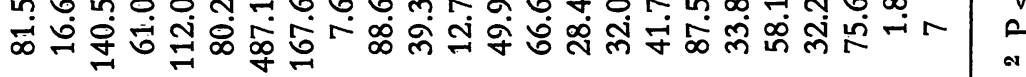

央 in oิ

"

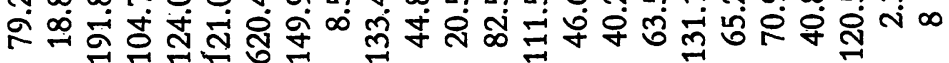

自

胥

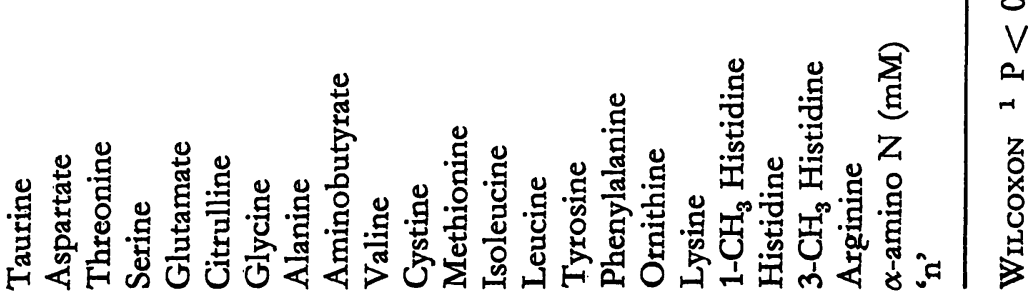




\subsection{Maternal plasma amino acid changes}

The changes in the plasma amino acids were very similar for the mothers of the control and infused groups of fetuses, and have been presented separately in Tab. IIIC and D. In contrast to the fetus, a fall of $18 \%$ and $25 \%$ in maternal plasma total $\alpha$-amino $\mathrm{N}$ occurred during the operation. This was due to a $20 \%$ and $40 \%$ reduction in serine, a $35 \%-50 \%$ fall in the branched chain amino acids isoleucine and leucine, and a $25 \%-38 \%$ fall in the basic amino acids, lysine and arginine; these changes were all significant $(P<0.05-0.001)$. The decrease in branched chain and basic amino acids was transitory, with the exception of arginine and the control levels were restored by the first or second post-operative days, at which levels they remained. The serine values remained low throughout the 14 days of observation.

Alanine fell slightly during hysterotomy in the control group of ewes but continued to fall so that a $35 \%$ reduction was observed two days after operation $(\mathrm{P}<0.05)$ and, thereafter, a slow rise was observed without normal values being reached in 14 days. In the mothers of the infused ewes, plasma alanine concentration rose slightly during the hysterotomy, but a fall of $30 \%$ occurred two days after the operation $(P<0.02)$ with recovery by seven days. Glycine fell progressively in the two groups and was $25 \%$ and $50 \%$ below the control values one to two days after hysterotomy; normal values were only achieved in the ewes of the control fetuses. A $30 \%$ and $50 \%$ reduction in glutamate $(P<0.10)$ on the first post-operative day was observed with recovery by five days. Citrulline levels were raised by $30 \%$ at the end of the observations in the control group, but fell by $50 \%$ before returning to the control levels at five days in the infused group. A transient rise in taurine of $40 \%-50 \%$ was seen in both groups on the first and second post-operative day, and a doubling of the $\alpha$-amino butyrate and $3-\mathrm{CH}_{3}$ histidine levels.

In the 1972 ewes, the post-operative fall in both alanine and glycine was marked in comparison with the 1973 mothers and frequently more than $50 \%$ of the control values, as was observed in their corresponding fetuses. Recovery during the subsequent 13 days was slow. Branched chain and basic amino acids were reduced post-operatively, but rose above control levels during two weeks in the mothers of fetuses which were not infused. However, a rise was observed in those amino acids given to the fetus in the infused group (Fig. 3). This was most marked for glycine in which a fourfold increase was found; valine, isoleucine and arginine were increased by $50 \%$.

\subsection{Blood urea and glucose, and hematocrite}

The mean values for fetal and maternal blood urea, blood glucose and hematocrite are shown in Fig. $4 a, b$ and c. The fetal urea values were $40 \mathrm{mg} \%$ about $5 \mathrm{mg} \%$ higher than the maternal levels. A decline to $30 \mathrm{mg} \%$ was observed in the control fetuses for a week after the operation, with subsequent recovery; the levels were sustained at $43 \mathrm{mg} \%$ in the infused fetuses. In the mothers of both control and infused fetuses, the blood urea declined from about $35 \mathrm{mg} \%$ to $27 \mathrm{mg} \%$ during two weeks. The relationship between maternal and fetal concentrations was linear with regressions of maternal on fetal concentration, ' $b$ ', of 0.92 (' $r$ ' $=0.95$ ) and 0.73 (' $r$ ' $=0.86$ ) for the control and infused groups with no significant difference between the two.

The fetal blood glucose levels lay between 40 and $60 \mathrm{mg} \%$ during the operative procedure; they declined to $20 \mathrm{mg} \%$ by the second postoperative day, and reached $30 \mathrm{mg} \%$ at nine days. The maternal levels were just over $60 \mathrm{mg} \%$ on the day following surgery, but remained about $60 \mathrm{mg} \%$ thereafter. The relation between maternal and fetal levels were linear, with regressions of fetal on maternal values, ' $b$ ', of 1.51 (' $r$ ' $=0.86$ ) for the control group, and 0.55 for the infused group (' $r$ ' $=0.42$ ).

The mean hematocrite values before the observations started were $34 \%$ and $38 \%$, while those for the first fetal samples were $40 \%$. Both maternal and fetal declined to between $35 \%$ and $30 \%$ during the week after operation with recovery to the control values by 14 days; the fetal levels were always higher than maternal.

\section{Discussion}

The tip of the catheter in the fetal jugular vein was near the entrance to the right auricle and 
1973
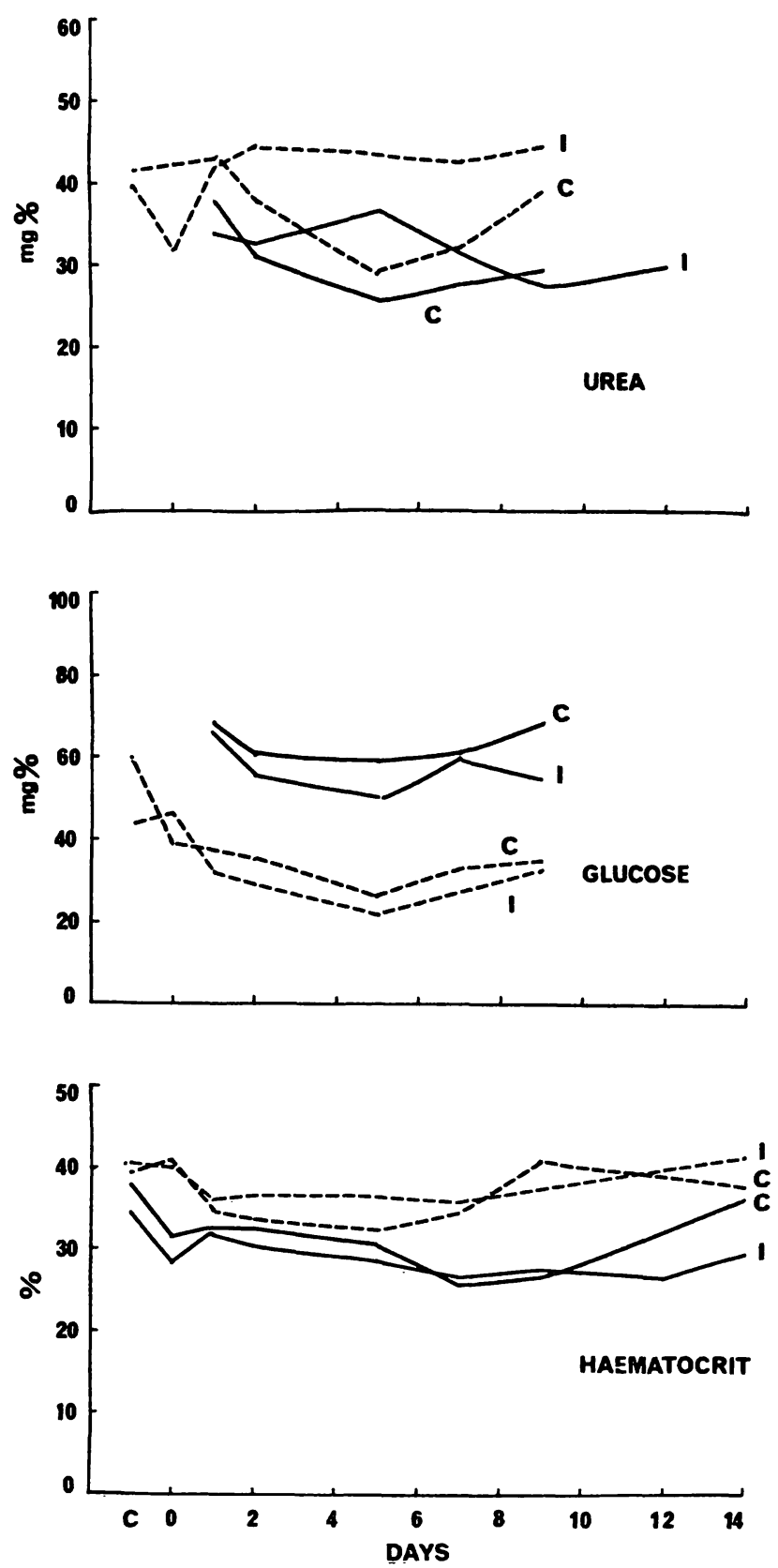

Fig. 4. Mean levels for blood urea, glucose and hematocrite during 8-14 days in control (C) and infused fetuses (I) and their mothers (1973). The number of values on each day are the same as in Tab. III

$\mathrm{C}=$ pre-operative $\mathrm{O}=$ post-operative.

since there was no free flow of blood from the head, the sample would be representative of blood returning from the liver which might account for the low concentrations of alanine and glycine observed in the control samples in comparison with those reported previously for umbilical vein and artery (Young and McFADYEN
[29]). However, the composition of the umbilical vein blood taken from the undisturbed twins, remaining 14 days 'in utero' after surgery to the sibling, though similar to the earlier reported values also have low alanine levels which suggests that the low jugular vein alanine might also be the result of fetal surgery. The amino acid composition of the maternal jugular vein samples, collected with a free flow of blood from the head, was similar to the arterial samples published for the Scottish Black Face ewes, except that the branched chain amino acids and lysine were about $40 \%$ higher, suggesting a dietary or species difference.

The rise in fetal plasma total $\alpha$-amino $\mathrm{N}$ during surgery and its subsequent recovery suggests some impairment of placental and fetal circulations and decreased tissue uptake of amino acids. Similar increases in plasma amino acid concentration have been observed following hemorrhage in the adult guinea pig (JoYCE et al. [16]). The changes in the individual amino acids during and after hysterotomy also suggest some disturbance of liver and muscle metabolism; raised taurine values are indicative of the former and 3-methyl-histidine of the latter (Young et al. [30]).

The most pronounced changes in the plasma homeostasis, a depression of all the gluconeogenic amino acids, particularly glycine, are similar to those found during the first one to three days of a fast in both man (Felig et al. [13]) and rats (Bloxam [6]). Such changes are, therefore, a general immediate response to a reduction in the supply of nutrients. The changes in the fetus are probably caused by a temporary fall in maternal blood flow, with a reduction in the placental transfer of glucose; the consequent increase in gluconeogenesis results in a reduction in the concentration of alanine, glycine and glutamic acid. Gluconeogenesis has been shown to occur from pyruvate in the livers of fetal lambs as early as 40 days gestation (BALLARD and Oliver [3]). It is possibly not so active in the fetus as it is in the adult (Felig [14]) for the levels of glucogenic amino acids are generally higher in fetal than maternal plasma; nevertheless, the mechanism must have been working efficiently because the fetal blood glucose levels were 
well maintained. The fall in the branched chain amino acids 24 hours after the operation, would also suggest a fall in maternal:fetal exchange, particularly as this fall was more marked after the more severe operative procedures. JOYCE et al. [16] have shown a reduction in transfer of both branched chain and basic amino acids with an impairment of maternal placental blood flow in the guinea pig. The rise in branched chain amino acid concentration found on the second post-operative day and, subsequently, is also characteristic of the early starvation period and has been attributed by FeLIG et al. [13] to hypoinsulinism in the human subject. A similar explanation may be valid in the lamb for the endocrine pancreas is responsive during the last trimester of pregnancy (BASSETT et al. [4]).

There is a further possible explanation for the fall in plasma gluconeogenic, and the early fall and late rise in branched chain amino acids, in these experiments, namely, a reduction in fetal skeletal muscle blood flow. This tissue contains $35 \%-80 \%$ of the total body pools of essential amino acids both free and bound (MunRo [19]) and the uptake of the amino acids by muscle is rapid in the growing animal (Soltesz et al. [23]). The muscle pool for the gluconeogenic acids is also at least $50 \%$ of that of the whole body. Skeletal muscle is also the tissue whose growth is the most retarded during experimental growth retardation, by embolising the maternal placental vascular bed (CREASY et al. [9]) and by maternal malnutrition (Sykes and Field [25]). The fundamental cause for this is probably a slight chronic hypoxia and the subsequent redistribution of the cardiac output to the brain and splanchnic organs (Creasy et al. [9] and CaMpBELL et al. [7]). In the present experiments, there may be a similar redistribution of the organ blood flow, so that the uptake of branched chain amino acids is reduced, hence their rise in the plasma, and the release of glucogenic amino acids may also be reduced, causing the fall in plasma concentration. Since the fetus is entirely dependent upon the maternal placental blood flow, the basic cause for the changes observed must be impairment of maternal:fetal exchange of oxygen and nutrients. However, the extent of the disturbance in amino acid homeostasis did not in- dicate such severe changes as are observed in the aminogram of Kwashiokor, with the characteristically elevated alanine and glycine levels, and depression of plasma branched chain concentrations (ADIBI [1]).

A continuous infusion of Amninosol glucose given to the fetus improved the uptake of the branched chain amino acids by the fetal tissues and their levels were not raised in the plasma of these fetuses. The experimental series was too small to show any statistical improvement in the outcome of the pregnancies by fetal weight, but it was interesting to observe that the livers of infused fetuses were heavier than in a control uncatheterised twin, and that the liver weight of a control catheterised fetus was lighter than that of the uncatheterised sibling (MCFADYAN et al. [17]). It is not known whether this increase in weight was due to active tissue but if it was, this might account for the continued low levels of plasma gluconeogenic amino acids observed.

The infusion of 'Trophysan' was not satisfactory on two accounts. Firstly, that the infusions were given over a shorter period and, secondly, that they contained the ' $\mathrm{D}$ ' isomers of the amino acids. However, these deficiencies allowed the observation of some characteristics of fetal amino acid uptake and fetal:maternal inter-relationships. Inspection of the levels of plasma amino acids before and after the hour long infusion, showed that the values of all free amino acids, besides those contained in the infused solution, were elevated. This demonstrates the suggestion by Christensen [8], that the overlap of amino acids transfer between the transport groups is such that overloading with one amino acid may influence the uptake of many others. The homeostatic mechanisms were such that the control levels had returned within 24 hours. The levels of the amino acids infused, however, gradually rose during 14 days due to the lack of utilisation of the ' $D$ ' isomer. In addition, there was a flux of these amino acids into the maternal circulation causing a smaller rise in her plasma levels. This was particularly marked for glycine which was given in large quantities to the fetus as a single source of non essential nitrogen. In one case, these high levels were transmitted to a twin fetus. A doubling of the resting serine and alanine 
levels were also observed demonstrating their inter-conversion from glycine; a rise in cystine and tyrosine levels was also found demonstrating the activity of cystathionage and phenyalanine hydroxylase in the lamb.

The plasma amino acid changes were much less marked in the mother than in the fetuses in the post-operative period, demonstrating the greater capacity for homeostasis of the adult animal. A fall in the glycogenic amino acids was, however, still characteristic and may be due to a temporary reduction in food intake and the need for increased gluconeogenesis; Felig et al. [12] found that pregnancy accelerated and exaggerated these changes in the fasting human. No rise in serine was observed, which is in contrast to the findings of these authors in the human subject and those for the fetus just described. The rise in taurine also suggests a degree of impairment of cystine metabolism by the liver. The marked but temporary fall in the concentration of branched chain amino acids during the operative procedure was an expected response to the infusion of glucose and was probably due to the release of insulin, as in other species (MUNRo [20]).

The post-operative fall in blood urea of the control fetuses and that of the mothers in both groups confirm MELLOR and SLATER's [18] observations in the ewe and those for the fetus, implied by the falling urea concentrations found in the allantoic fluid in the days following surgery. The results suggest an inhibition of urea synthesis in both the mother and fetus following the hysterotomy; this is apparently in contrast to the findings of O'KEEFE et al. [21] that moderate surgery reduces protein synthesis rate, but has little influence on protein breakdown. The feto: maternal

\section{Summary}

Intra-uterine surgery for the introduction of indwelling catheters 'in utero' into the blood vessels of the fetal lamb causes some distrubance of homeostasis in both mother and fetus. The influence of this operative procedure, under Ketalar anesthesia, on plasma amino acid homeostasis is described in this paper, together with the effect of a continuous infusion of amino acids and glucose on the changes observed. The intravenous nutritional supplement was given to the fetus during a two week period.

The abdominal surgery and hysterotomy required for the cannulation of the fetal jugular vein caused changes in the blood urea gradient did not alter in the postoperative period in control animals, in contrast with the fall observed in the arterial transplacental gradient by Battglia and Meschia [5]. The fetal plasma urea concentrations did not fall when aminosol glucose was infused, but the transplacental gradients were smaller due to the fall in the maternal levels.

Finally, it may be suggested that nitrogen homeostasis, as judged by plasma alanine and glycine levels, is a more sensitive method of detecting fetal wellbeing 'in utero' than that of glucose homeostasis.

\section{Appendix}

\section{Nutritional Requirements of Lamb}

(see also Tab. I)

An average fetal nitrogen requirement of $1.6 \mathrm{~g}$ per day, equivalent to $10 \mathrm{~g}$ protein was estimated from the average daily weight increment of $60 \mathrm{~g} /$ day, between 90 and 150 days gestation (WALl_ACE [28]) and the protein content, $623 \mathrm{~g}$ of a $4 \mathrm{~kg}$ fetus at term (SYkes and Field [26]). The daily glucose requirement of a $3 \mathrm{~kg}$ fetus, $34 \mathrm{~g}$, was calculated from the glucose utilisation rate of $8 \mathrm{mg} / \mathrm{kg} / \mathrm{min}$ measured by DAwes and SHELlEY [11] using the FICK principle from umbilical vein - artery differences and blood flow. This glucose utilisation figure is high in comparison with that of other workers (BATtaglia and Meschia [5] and Crenshaw et al. [10]) using similar methods in chronic preparations with indwelling fetal catheters; but the energy equivalent, $130 \mathrm{Kcal}$, is only half that expected from observations on the heat increment of pregnancy in the ewe, $90 \mathrm{Kcal} / \mathrm{kg}$ fetus/day (GrahAm [15]).

fetal plasma free amino acids which are shown in Tab. III A and $\mathbf{B}$, together with the significance of their differences from the first control sample taken at operation. The main characteristics of these changes are as follows:

1. During the operation, the fetal plasma total $\alpha$-amino rose by $13 \%$, a rise of $40 \%$ in the taurine value, $12 \%$ for threonine and $44 \%$ for $\alpha$-aminobutyrate contributed to this; small increases in alanine and 1 and 3 methyl histidine were observed. The levels of the branched chain amino acids were little changed, while falls of $10 \%-30 \%$ werc observed for the basic amino acids. 
2. Twenty-four hours following surgery, the most prominent feature of the amino acid pattern was significant falls in glutamate $(30 \%)$, glycine $(18 \%)$ and alanine $(32 \%)$, and $9 \%-32 \%$ reductions in the branched chain amino acids valine, isoleucine and leucine; $\alpha$-amino butyrate and 1 and 3 methyl histidine continued to rise.

3. On the second post-operative day, the plasma amino acid changes were indicative of the pattern during the subsequent 14 days. Glycine levels returned to control values but glutamate and alanine remained low (Fig. 1). Serine showed a peak at $45 \%$ above control values and subsequently declined. The branched chain amino acids were elevated by $23 \%-42 \%$ and remained high. The basic amino acid concentrations remained near their control levels. Taurine, $\alpha$-amino butyrate and the methyl histidines remained high at about double their control levels. The concentration of citrulline was also elevated.

The infusion of 'Aminosol Glucose' to the fetus equivalent to $1 / 3 \mathrm{rd}$ of its daily requirements of nitrogen and glucose, (see Tabs. I and II) during 14 days had no marked influence on these post-operative changes in plasma free amino acid hoemostasis. This is shown in Fig. 2 in which the levels of three straight chain neutral amino acids, serine, glycine and alanine, three branched chain neutral, valine, isoleucine and leucine, and three basic, lysine, histidine and arginine amino acid levels are shown throughout the infusion period in an individual fetus from each of the two groups, control and infused. The relative lability of the neutral straight chain free amino acids is observed in both the fetuses, and their mothers, in comparison with the constancy of the neutral branched chain and basic amino acid levels. Fig. 3 shows the changes during a 'Trophysan' infusion into the fetus 'in utero'; this caused a rise in concentration of many of the amino acids which the solution contained due to the presence of the ' $\mathrm{D}$ ' isomer (Tab. II). This rise was reflected in the maternal plasma demonstrating some fetal to maternal flux, particularly of glycine which was present in high concentrations in the infusion.

The rise in many of the fetal plasma amino acids during the operation, and the subsequent recovery, suggests some slowing of the fetal circulation with decreased uptake by the tissues. The characteristic fall during the first two postoperative days of the gluconeogenic amino acid plasma concentration and elevation of the branched chain levels is very similar to the changes found during the first days of starvation in the adult; this suggests that there has been impairment of placental exchange, particularly as the pattern is enhanced with more severe surgery. This pattern of change might also be due to skeletal.muscle vasoconstriction with impaired release of straight chain amino acids and uptake of branched chain. The raised taurine values suggested liver damage and elevated 3 methyl histidine values muscle catabolism. Elevated citrulline concentrations with low arginine values also suggests inhibition of the citrulline-arginine cycle.

Blood glucose values were similar in both control and infused fetuses suggesting good responsiveness of the regulating mechanisms (Fig. 3). Blood urea levels were initially depressed in control fetuses, but maintained in the infused fetuses.

Post-operative changes in the maternal plasma amino acid homeostasis were very similar to those described for the fetus, but of a lesser degree and with more complete recovery after seven days (Tab. III, C, D and Fig. 1). Again, blood glucose levels were maintained but blood urea values temporarily depressed (Fig. 3).

Keywords: Fetal intravenous supplements, intra-uterine surgery, plasma amino acids.

\section{Zusammenfassung}

Der Einfluß eines intrauterinen operativen Eingriffes und einer intravenösen fetalen Zusatzernährung in utero auf die freie Aminosäurehomöostase im Plasma beim schwangeren Schaf

Ein intrauteriner operativer Eingriff zum Einlegen von Dauerkathetern in die Blutgefäße des in utero liegenden Lammfeten verursacht sowohl bei der Mutter wie beim Fetus Störungen der Homöostase. In dieser Arbeit wird der Einfluß dieser operativen Maßnahme, die unter Ketalar-Anästhesie durchgeführt wurde, auf den Plasmaaminosäurespiegel beschrieben; gleichzeitig wird der Effekt einer kontinuierlichen Infusion von Aminosäuren und Glukose auf die beobachteten Veränderungen dargestellt. Die intravenöse Zusatzernährung wurde über einen Zeitraum von 2 Wochen hinweg dem Feten verabfolgt.

Der abdominale Eingriff und die für die Kannülierung der fetalen Vena jugularis notwendige Hysterotomie verursachen Veränderungen der fetalen Plasma-Aminosäuren. Diese Veränderungen sind in Tab. III A und B einschließlich der Signifikanz ihrer Abweichungen von den ersten
Kontrollproben während der Operation dargestellt. Die wesentlichen Veränderungen lassen sich wie folgt beschreiben:

1. Während der Operation steigt der Gehalt an $\alpha$-Aminosäuren im fetalen Plasma um $13 \%$ an. Daran sind die Aminosäuren Taurin mit $40 \%$, Threonin mit $12 \%$ und $\alpha$-Aminobutyrat mit $44 \%$ beteiligt. Ein geringer Anstieg von Alanin und 1- sowie 3-Methylhistidin wurde beobachtet. Die Spiegel für die verzweigtkettigen Aminosäuren waren gering verändert, wohingegen ein Abfall der basischen Aminosäuren um 10 bis 30\% beobachtet wurde. 2. 24 Stunden nach dem Eingriff bestanden die markantesten Veränderungen des Aminosäurespektrums in dem signifikanten Abfall von Glutaminsäure (30\%), Glykokoll (18\%) und Alanin (32\%), sowie eine Reduktion der verzweigtkettigen Aminosäuren Valin, Isoleucin und Leucin um 9-32\%. $\alpha$-Aminobuttersäure und 1- sowie 3-Methylhistidin stiegen weiterhin an.

3. Am zweiten postoperativen Tag waren die Aminosäurespiegel im Plasma repräsentativ für das Spektrum derselben während der folgenden 14 Tage. Der Glykokoll- 
spiegel kehrt zum Ausgangswert zurück, während die Glutamat- und Alanin-Spiegel tief bleiben (Fig. 1). Serin zeigte einen Peak von $45 \%$ über den Kontrollwerten und fällt in der Folge ab. Die verzweigten langkettigen Aminosäuren waren um $23-42 \%$ erhöht und blieben hoch. Die Spiegel der basischen Aminosäuren blieben im Niveau der Kontrollwerte. Taurin, $\alpha$-Aminobutyrat und die Methylhistidine hielten sich beim Doppelten ihrer Kontrollwerte. Die Konzentration von Citrullin war ebenfalls erhöht.

Die Infusion von "Aminosol-Glukose“ an den Feten während 14 Tagen in einer Dosierung, die einem Drittel des täglichen Bedarfes an Stickstoff und Glukose (s. Tab. I und II) entsprach, hatte keinen merklichen Einfluß auf diese postoperativen Veränderungen der freien Aminosäurespiegel im Plasma. Dies ist in Fig. 2 zusammengestellt. Diese Abbildung zeigt die Spiegel von drei geradkettigen neutralen Aminosäuren, nämlich Serin, Glycin und Alanin, drei verzweigtkettigen neutralen Säuren, Valin, Isoleucin und Leucin und drei basischen Verbindungen, I,ysin, Histidin und Arginin während der Infusionsperiode bei einem einzelnen Fetus jeweils aus einer der beiden Gruppen, also der Kontroll- und der Infusions-Gruppe. Es wurde eine relative Instabilität der Spiegel der neutralen geradkettigen freien Aminosäuren sowohl bei den Feten wie ihren Muttertieren beobachtet im Vergleich zur Konstanz der neutralen verzweigtkettigen und basischen Aminosäurenspiegel. Fig. 3 gibt die Veränderungen während einer "Trophysan" Infusion an den Fetus in utero wieder. Diese Infusion verursacht einen Anstieg der Konzentration von vielen Aminosäuren, welche in der Lösung enthalten sind bedingt durch die Anwesenheit der "D" Isomeren (Tab. IJ). Dieser Anstieg fand seinen Niederschlag im mütterlichen Plasma, was den fetomaternalen Austausch speziell für die Aminosäure Glycin demonstriert, welch letztere in hohen Konzentrationen in der Infusion enthalten war. Der Anstieg vieler fetaler Plasmaaminosäuren während der Operation und die nachfolgende Normalisierung läßt die Vermutung $z u, d a ß$ es $z u$ einer
Verlangsamung der fetalen Zirkulation mit herabgesetzter Aufnahme der Aminosäuren durch die Gewebe gekommen ist. Der charakteristische Abfall der glukoplastischen Aminosäurenplasmakonzentrationen und der Anstieg der verzweigten langkettigen Aminosäuren während der ersten beiden postoperativen Tage gleicht sehr stark jenen Veränderungen, die man beim Erwachsenen während der ersten Tage einer Fastenperiode beobachtet. Dies legt die Vermutung nahe, daß es zu einer Beeinträchtigung des plazentaren Austausches gekommen ist, insbesonderc insofern, als das Verhaltensmuster der Aminosäurenspiegel mit der Schwere des operativen Eingriffes im Zusammenhang steht.

Die beobachteten Veränderungen könnten auch durch Vasokonstriktion im Bereich der Skelettmuskulatur bedingt sein; diese verursacht eine Bseinträchtigung der Abgabe von geradkettigen Aminosäuren und die Aufnahme von verzweigtkettigen Verbindungen. Die erhöhten Taurinwerte lassen eine Leberschädigung und die erhöhten 3-Methylhistidinwerte einen Muskelkatabolismus vermuten. Erhöhte Citrullinkonzentrationen in Verbindung mit tiefen Argininwerten weisen auf eine mutmaßliche Hemmung des Citrullin-Arginin-Zyklus hin.

Die Blutglukosewerte waren sowohl bei den zur Kontrolle dienenden, wie bei den infundierten Feten gleich, was ein gutes Ansprechen der beteiligten Regulationsmechanismen vermuten läßt (Fig. 3). Die Blutharnstoffwerte waren anfangs erniedrigt bei den Kontrolltieren, hielten sich jedoch konstant bei den Feten mit Infusion.

Die postoperativen Veränderungen in den mütterlichen Plasmaaminosäurekonzentrationen waren ganz ähnlich denen, die beim Feten beschrieben wurden; sie waren jedoch weniger stark ausgeprägt und kehrten nach 7 Tagen vollständiger zur Norm zurück (Tab. III C, D und Fig. 1). Wiederum waren die Blutglukosespiegel konstant, während die Blutharnstoffwerte vorübergehend absanken (Fig. 3).

Schlüsselworte: Fetale intravenöse Zusatzernährung, intrauteriner operativer Eingriff, Plasmaaminosäurespiegel.

\section{Résumé}

L'influence de la chirurgie intra-utérine et des suppléments nutritionnels intraveineux foetaux «in utero» sur l'homeostasis des acides aminés libres dans le plasma de la brebis gestante

La chirurgie intra-utérine pour l'introduction de sondes à demeure «in utero» dans les vaisseaux sanguins de l'agneau foetal provoque un certain trouble de l'homéostasis à la fois chez la mère et chez le foetus. Le présent article traite de l'influence de cette méthode opératoire, sous anesthésie Ketalar, sur l'homéostasis des acides aminés du plasma ainsi que de l'effet d'une infusion continue des acides aminés et du glucose sur les changements observés. Le foetus avait reçu pendant deux semaines un supplément nutritionnel intraveineux.

La chirurgie abdominale et l'hystérotomie requises pour la canulation de la veine jugulaire foetale ont provoqué des changements dans les acides aminés libres du plasma foetal ainsi qu'on peut le voir aux Tab. III A et B qui expliquent aussi les différences relevées entre ces changements et le premier échantillon de contrôle prélevé à l'opération. Ces modifications comportent les principales caractéristiques suivantes:

1. Au cours de l'opération, les acides aminés $\alpha$ total du plasma foetal montent de $13 \%$, ce à quoi contribuèrent une hausse de $40 \%$ dans la valeur de taurine, de $12 \%$ pour la thréonine et de $44 \%$ pour l'aminobutyrate $\alpha$; on observa de légères hausses dans l'alanine et dans l'histidine de méthyle 1 et 3 . Les taux d'acides aminés dérivés ont peu changé tandis qu'on releva des baisses de 10\%-30\% dans les acides aminés basiques.

2. 24 heures après l'opération on observa au tableau des acides aminés surtout des baisses significatives du gluta- 
mate $(30 \%)$, de la glycine (18\%) et de l'alanine (32\%), et des réductions de $9 \%-32 \%$ dans la valine, l'isoleucine et la leucine des acides aminés dérivés; l'amino-butyrate $\alpha$ et l'histidine de méthyle 1 et 3 continuèrent d'augmenter.

3. Le deuxième jour post-opératoire, les changements relevés dans les acides aminés du plasma furent significatifs à leur égard pour les 14 jours consécutifs. Les taux de glycine remontèrent aux valeurs de contrôle, mais le glutamate et l'alanine restèrent bas (Fig. 1). La sérine atteignit une hausse maximale de $45 \%$ au-dessus des valeurs de contrôle pour redescendre ensuite. Les acides aminés dérivés montèrent à $23 \%-42 \%$ et restèrent élevés. Les concentrations d'acides aminés basiques se fixèrent près de leurs niveaux de contrôle. La taurine, l'aminobutyrate $\alpha$ et les histidines de méthyle restèrent à un niveau environ double de leurs niveaux de contrôle. La concentration de citrulline était également élevée.

L'infusion de "glucose aminosol» au foetus correspondant à un tiers de ses besoins quotidiens en nitrogène et glucose (cf. Tab. I et II) durant 14 jours n'a pas eu d'influence marquée sur ces changements post-opératoires dans l' homéostasis des acides aminés libres du plasma, ainsi qu'on peut le voir à la Fig. 2 où les taux de trois acides aminés neutres droits: sérine, glycine et alanine, de trois accides aminés neutres dérivés: valine, isoleucine et leucine, et de trois acides aminés basiques: lysine, histidine et arginine sont indiqués tout au long ae la période d'infusion dans un foetus individuel de chacun des deux groupes de contrôle et infusé. La labilité relative des acides aminés libres neutres droits apparait chez les foetus et leurs mères tandis qu'on a pu observer une constance dans les taux des acides aminés neutres dérivés et basiques. La Fig. 3 illustre les changements durant une infusion de "trophysan» dans le foetus "in utero»; cette infusion a provoqué une hausse dans la concentration de nombreux acides aminés que la solution contenait par suite de la présence de l'isomer «D» (Tab. II).
Cette hausse se refléta dans le plasma maternel qui révéla un certain flux du foetus dans la mère notamment de glycine présente en concentrations élevées dans l'infusion.

La hausse observée dans beaucoup d'acides aminés du plasma foetal au cours de l'opération et le rétablissement consécutif font suggérer un certain ralentissement dans la circulation foetale avec reprise décroissante par les tissus. La baisse caractéristique durant les deux premiers jours post-opératoires de la concentration des acides aminés gluconeogéniques du plasma et l'élévation des taux dérivés sont très similaires aux changements trouvés durant les premiers jours de privation de nourriture chez l'adulte; cela donne à penser qu'il y a eu altération de l'échange placentaire, surtout en cas d'intervention chirurgicale plus intensive. Ce tableau de changement peut donc être dû à une vasoconstriction musculaire squelettique aveclibération affaiblie des acides aminés droits et augmentation des dérivés. Les valeurs élevées de taurine font suggérer une lésion du foie et les valeurs élevées de l'histidine de méthyle 3 un catabolisme musculaịre. Les concentrations élevées de citrulline avec des valeurs basses d'arginine font aussi supposer une inhibition du cycle citrulline-arginine.

Les valeurs de glucose sanguin ont été similaires dans le groupe de contrôle et les foetus infusés, ce qui fait supposer une bonne réaction du mécanisme régulateur (Fig. 3). Les taux d'urée sanguine ont baissé au début chez les foetus de contrôle, mais se sont maintenus chez les foetus infusés.

Les changements post-opératoires observés dans 1'homéostasis des acides aminés du plasma maternel ont été très similaires à ceux décrits pour le foetus, mais d'un degré moindre et avec un rétablissement plus complet au bout de 7 jours (Tab. III C, D et Fig. 1). En outre, les taux de glucose sanguin se sont maintenus, mais les valeurs d'urée sanguine ont baissé temporairement (Fig. 3).

Mots-clés: Acides aminés du plasma, chirurgie intra-utérine, suppléments intraveineux foetaux.

\section{Acknowledgements}

Our grateful thanks are due to Mrs. Sylvia Chrystie for the amino acid analyses and to Miss Lyndsay Nelson, B. Sc. for the statistical analyses: also to the M.R.C. for the support of Mrs. JenNy JoyCE, B. Sc. and to the Wexlcome Trust for the purchase of the Technicon Amino Acid Analyser.

\section{Bibliography}

[1] ADIBI, S. A.: Influence of dietary deprivation on plasma concentration of free amino acids in man. J. Appl. Physiol. 25 (1968) 52

[2] Archer, H. E., G. D. Robi: The tolerance of the body for urea in health and disease. Quart. J. Med. 18 (1925) 274

[3] Ballard, F. J., I. T. Oliver: Carbohydrate metabolism in liver from fetal and neonatal sheep. Biochem. J. 95 (1965) 191

[4] Bassett, J. M., D. Madill, D. H. Nicol, G. D. Thorburn: Further studies on the regulation of insulin release in fetal and post-natal lambs; the role of glucose as a physiological regulator of insulin release 'in utero'. In: "Fetal and Neonatal Physiology", University Press, Cambridge 1973

[5] Battaglia, F. C., G. Meschia: 'Fetal metabolism and substrate utilization'. In: “Fetal and Neonatal Physiology", University Press, Cambridge 1973

[6] Bloxam, D. C.: Nutritional aspects of amino acid metabolism. 2. The effects of starvation on hepatic portal-venous differences in plasma amino acid concentration and on liver amino acid concentrations in the rate. Brit. J. Nutr. 27 (1972) 233

[7] Campbeli, A. G. M., G. S. Dawes, A. P. Fishman, A. T. Hyman: Regional redistribution of blood flow in the mature fetal lamb. Circln. Res. 21 (1967) 229 
[8] Christensen, H. M.: Relevance of transport across the plasma membrane to the interpertation of the plasma amino acid pattern. In: I.eAthaM, J. H. (edit.): 'Protein Nutrition and Free Amino Acid Patterns'. Rutgers University Press, New Jersey 1968

[9] Creasey, R. K., M. de Swiet, K. V. KahanpaA, W. P. Young, A. M. Rudolpri: Patho-physiological changes in the fetal lamb with growth retardation in Fetal and Neonatal Physiology. University Press. Cambridge 1973

[10] Crenshaw, C., R. Cefalo, D. W. Schomberg, L. B. Curet, D. H. Barron: Estimations of the umbilical uptake of glucose by the fetal lamb. In: 'Fetal and Neonatal Physiology'. University Press, Cambridge 1973

[11] Dawes, G. S., H. J. Shelley: 'Physiological aspects of carbohydrate metabolism in the fetus and newborn'. In: Dickins, F., P. J. Randle, W. J. Whielan: 'Carbohydrate Metabolism and its disorders', Academic Press, London-New York 1968

[12] Felig, P., Y. J. Kim, V. Lynch, R. Hendler: Amino acid metabolism during starvation in human pregnancy. J. Clin. Invest. 57 (1972) 1195

[13] Felig, P., O. E. Owen, J. Wahren, F. G. Cahill: Amino acid metabolism during prolonged starvation. J. Clin. Invest. 48 (1969) 584

[14] Felig, P., T. Pozefsky, E. Marliss, G. F. Cahill: Alanine: key role in gluconeogenesis. Science 167 (1970) 1003

[15] McGraham, N.: Energy exchanges of pregnant and lactating ewes. Aus. J. Agric. Res. 15 (1964) 127

[16] Joyce, J., M. Young, P. M. M. Hirl: The influence of a reduction in maternal placental blood flow on the placental transfer of glucose and amino acids (in preparation.)

[17] McFadyen, I. R., D. Noakes, J. Joyce, M. Young, Gà. Soltesz, B. V. LEwis: Intravenous feeding of the fetus 'in utero'. Proc. 4th European Congress of Perinatal Medicine (1974)

[18] Mellor, D. J., J. S. Slater: Early changes in amniotic and allantoic fluid during the last three months of pregnancy in conscious, unstressed ewes with catheters in their fluid sacs. J. Physiol. 217 (1971) 573

[19] Munro, H. N.: Evolution of protein metabolism in mammals. In: Munro, H. N.: Mammalian Protein Metabolism. Academic Press, New York-London 1969

[20] Munro, H. N.: Specific action of dictary carbohydrate. In: Munro. H. N.: Mammalian Protein Metabolism. Academic Press, New York-London. 1970

[21] O'Keefe, S. J. D., P. M. Sender, C. G. Clark, W. P. T. JAMES: The dynamics of protein metabolism following opcrative trauma. Clin. Sci. and Mol. Med. 47 (1974) 15P

[22] Shelley, H. J.: The use of chronically catheterised fetal lambs for the study of fetal metabolism. In, "Fetal and Neonatal Physiology". University Press, Cambridge 1973

[23] Soltesz, Gy., J. Joyce, M. Young: Protein synthesis rate in the newborn lamb. Biol. Neonate. 23 (1973) 139

[24] Stern, W. H., S. Moore: The free amino acids of human blood plasma. J. biol. Chem. 211 (1954) 915

[25] Sykes, A. R., A. C. Field: Effects of dietary deficiences of energy, protein and calcium on the pregnant ewe. II. Body composition and mineral content of the lamb. J. agric. Sci. Camb. 78 (1972) 119

[26] Sykes, A. R., A. C. Freld: Some observations on the use of biochemical parameters controlling energy undernutrition during pregnancy and on the efficiency of utilisation of energy and protein for fetal growth. J. agric. Sci. Camb. 78 (1972) 127

[27] TaO, R. C., G. W. Wolfram, J. M. Asphind: Total parental alimentation to study amino acid nutrition of the sheep. Nutr. Rep. Internat. 8 (1973) 405

[28] Wallace, L. R.: The growth of lambs before and after birth in relation to the level of nutrition J. agric. Sci. Camb. 38 (1948) 367

[29] Young, M., I. R. McFadyen: Placental transfer and fetal uptake of amino acids in the pregnant ewe. J. Perinat. Med. 1 (1973) 174

[30] Young, V. R., S. D. Alexis, B. S. Baiga, H. N. Munro: Metabolism of adminstered 3-methyl histidine. J. Biol. Chem. 247 (1972) 3590

Maureen Young

St. Thomas's Hospital Medical School

Dept. of Gynecology

London, S. E. $17 \mathrm{EHI}$ 